\title{
APP-077 レスベラトロールの勃起機能回復効果の検討
}

\section{大阪大学大学院医学系研究科器官制御外科学（泌尿器科）}

福原 慎一郎, 奥田 英伸, 山本 圭介, 中山 治郎, 高尾 徹也, 宮川 康, 过村 晃, 奥山 明彦 【目的】われわれはこれまで、ヒト陰茎海綿体平滑筋細胞（CCSMC）がNO 合成酵素（eNOS）を発現し、さらに実 際にNO を産生していることを報告してきた。また、近年長寿遺伝子として注目を集めている SIRT1 が血管内皮細 胞において eNOS を活性化させることにより血管拡張に寄与していることが報告されている。そこで、CCSMCに扔 けるSIRT1の役割の検討を行い、CCSMCにおいてもSIRT1が存在していること、また、ポリフエノールの一種で SIRT1 の活性化物質であるレスベラトロールを加えることにより、CCSMC 内の CGMPが上昇することを報告して きた。今回、勃起不全（ED）モデルとしてストレプトゾトシン（STZ）誘発糖尿病ラットを作成し、レスベラトロー ルの実際の勃起機能に対する効果の検討を行った。【方法】 8 週齢の SD ラット (雄) に STZ50mg/ $\mathrm{kg}$ を腹脭内投与し、 1 週後の血糖值が $250 \mathrm{mg} / \mathrm{dl}$ を超えたものを糖尿病ラットとし、勃起不全モデルとして使用した。STZ腹腔内投与後 4 週間、無治療糖㽷病状態で飼育し、STZ 投与 4 週後よりレスベラトロール $(5 \mathrm{mg} / \mathrm{kg} / \mathrm{day})$ を 4 週間内服投与した。 また、同時にPDE5 inhibitor内服の効果、およびレスベラトロールおよび PDE5 inhibitor 内服群との併用効果を検 討するため、PDE5 inhibitor としてバルデナフィル $(0.5 \mathrm{mg} / \mathrm{kg} / \mathrm{day})$ 内服群、レスベラトロール＋バルデナフィル 兩者併用内服群も合わせて検討し、それぞれ 4 週間各種薬剂を投与した。 4 週間内服後、1 日間薬剂の wash out を行っ た後、全身麻酔下に海面体神経の電気刺激 $(0.2 \mathrm{~ms} 15 \mathrm{~Hz} 2.5 \sim 7.5 \mathrm{~V})$ を行い、陰茎海綿体内圧（ICP）、平均動脈圧 (MAP) を測定し、ICP/MAP の值により勃起機能の評価をおこなった。また、ICP 測定後、陰茎組織を摘出し、陰 茥重量の比較、および AZAN 染色を行い陰茎海綿体内の平滑筋/colloagen の面積比を測定し比較、その他検討を行っ た。【結果】正常ラットに比べ、無治療糖尿病群ではICP/MAP の低下を認めたが、レスベラトロール内服群では無 治療群に比べICP/MAP が有意に回復し、さらに両剤併用群では、更なる回復効果を認めた。また、レスベラトロー ル内服群では陰茎重量、および、㓌茎海綿体内の平滑筋/collagen 比も回復していた。【考察】レスベラトロールは 糖尿病勃起不全動物モデルにおいて、有意に勃起機能回復効果を認めた。今後、糖尿病などの PDE5 inhibitorにて 治療に難渋する症例など、勃起不全の新たな治療薬としての可能性を有しているものと考えられた。

\section{APP-078Ｂ7-H4 ノックアウトマウスを用いた自己免疫性腎炎の解析と治療法の開発}

\section{東京都立府中病院泌尿器科1), ジョンズホプキンス大学Sidney Kimmel癌センター腫瘍科 ${ }^{2)}$, 東京大学医学部泌尿器 外科学 ${ }^{3)}$}

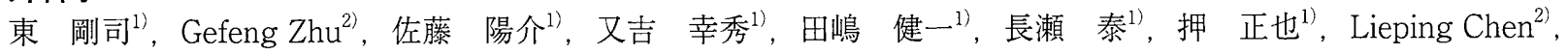
本間 之夫 ${ }^{3)}$

【目的】これまでに我々はImmunoglobulin superfamilyに属するI 型膜貫通型蛋白であるB7-H4 をクローニングし、ノックアウトマウス（B7H4KO）を作成、その機能を解析し膜型の B7-H4 は T 細胞と好中球への抑制作用を有することを発見した。また最近、自己免疫疾患患者やマ ウスの自己免疫疾患モデルの血清中に cleavage された可溶型 B7-H4 が存在すること、さらに可溶型 B7-H4 の投与で症状の增悪を認めること より、可溶型B7-H4 は Decoy として膜型 B7-H4の機能を抑制することを報告した。今回、B7-H4 の自己免疫性腎炎への関与を解析した。【方法】 lpr/lpr マウスはFasに変異を認め、腎炎を含め自己免疫性の疾患を自然発症する。マウスの strain が MRLを background とする MRL-lpr/ lpr は非常に強い Phenotype を示し、30 週頃に腎不全で死亡する、一方 C57BL6 background とする B6-lpr/lpr は Phenotype が弱いことが わかっている。MRL-lpr/lpr の血清中の可溶型 B7-H4 濃度を Sandwich ELISA 法にて測定し、可溶型 B7-H4 濃度と自己抗体との関連を解析し た。次にB6-lpr/lpr と B7-H4KO を交配させ B6-lpr/lpr x B7-H4KO を作成し、予後と病態を解析した。腎炎の治療モデルとしてIgG2aの FC domain と B7-H4の Extracellular domain とを結合させた Fusion protein（B7-H4Ig）を作成し、MRL-lpr/lprに自己抗体である anti-dsDNA 抗体が血清に認められ始める12週より14、16、18週と2週間間隔で計4回B7-H4Igを Hydorodynamic Injectionにて投与し、同様に解析した。【結 果】マウスの自己免疫性腎炎の自然発症モデルである MRL-lpr/lpr の血清中に可溶型 B7-H4 が認め、その濃度と自己抗体産生が相関すること がわかった。可溶型 B7-H4 は膜型 B7-H4に対する抑制作用を有することより、B6-lpr/lpr x B7-H4KO を作成し解析した。驚くべきことにB6lpr/lpr x B7-H4KO は 49 週までに 80\%が死亡したのに対して、B6-lpr/lpr はすべて生存した（p<0.05）。B6-lpr/lpr x B7-H4KOでは、リン パ節と脾臓の著明な腫大、血清中の anti-dsDNA 抗体の増加を示した $(\mathrm{p}<0.001)$ 。また、尿蛋白の増加を認め $(\mathrm{p}<0.05)$ 、病理学的検討では、 糸球体の cellularity の増加、メザンギウム細胞の増加、血管周囲から間質への細胞浸潤、IgG と C3 の系球体への沈着と腎炎の像を呈してい た。また、これらの現象は好中球を介していることが示唆された。次にMRL-lpr/lpr 用いた治療モデルでは、38週までにでコントロール群 は全て死亡した。一方 B7-H4Ig 投与群は 50\%が生存した（ $\mathrm{p}<0.05 ）$ 。B7-H4Ig 投与群ではリンパ節、脾臓の腫大が抑制され、血清中の antidsDNA 抗体と尿蛋白の減少、病理学的に腎炎の改善を認めた。【考察】B7-H4が自己免疫性腎炎に深く関与していること、さらにB7-H4Ig 利用した治療も有望であることが示唆された。現在我々は人の B7-H4Igを作成し臨床応用に向けて準備中である。 